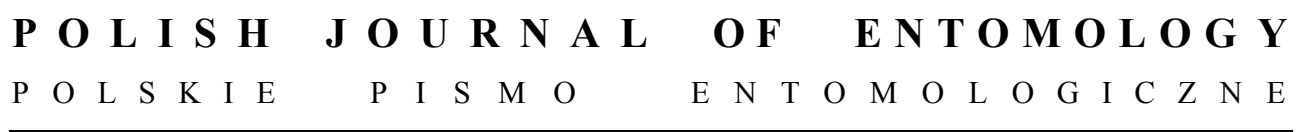

VOL. 80: 627-644

Gdynia

31 December 2011

DOI: $10.2478 / \mathrm{v} 10200-011-0049-5$

\title{
A new family of Coreoidea from the Lower Cretaceous Lebanese Amber (Hemiptera: Pentatomomorpha)
}

\author{
DANY AZAR ${ }^{1}$, ANDRÉ NEL ${ }^{2}$, MiCHAEL S. ENGEL ${ }^{3,4}$, ROMAIN GARROUSTE ${ }^{2}$, \\ ARMAND MATOCQ ${ }^{2}$ \\ ${ }^{1}$ Lebanese University, Faculty of Sciences II, Department of Natural Sciences, \\ PO box 26110217, Fanar - Matn, Lebanon, e-mail: azar@mnhn.fr; \\ ${ }^{2}$ CNRS UMR 7205, CP 50, Entomologie, Muséum National d'Histoire Naturelle, \\ 45 rue Buffon, F-75005 Paris, France, e-mails: anel@mnhn.fr, garroust@mnhn.fr, \\ matocq.armand@wanadoo.fr; \\ ${ }^{3}$ Division of Entomology (Paleoentomology), Natural History Museum, \\ University of Kansas, Lawrence, KS 66049-2811, USA, e-mail: msengel@ku.edu; \\ ${ }^{4}$ Department of Ecology \& Evolutionary Biology, 1501 Crestline Drive - Suite \\ 140, University of Kansas, Lawrence, KS 66049-2811, USA
}

\begin{abstract}
A new genus and species, Yuripopovina magnifica, belonging to a new coreoid family, Yuripopovinidae (Hemiptera: Pentatomomorpha), is described and illustrated from the Lower Cretaceous amber of Lebanon. The species represents the first definitive Mesozoic record for the Coreoidea. A cladistic analysis of Coreoidea, including the new family, is undertaken.
\end{abstract}

KEY WORDS: Pentatomomorpha, Coreoidea, Yuripopovinidae, fam. n., gen. n., sp. n., Lebanon, phylogeny.

\section{INTRODUCTION}

The Pentatomomorpha with its 14000 known living species (WEIRAUCH \& SCHUH 2011) is the second largest of the seven heteropteran infraorders (SCHAEFER 1993, S̆TYS \& KERZHNER 1975) (Enicocephalomorpha, Dipsocoromorpha, Gerromorpha, Nepomorpha, Leptodomorpha, Cimicomorpha, and Pentatomorpha). Most authors recognize five superfamilies within Pentatomomorpha, but there remains controversy regarding the 
composition of these superfamilies (SCHAEFER 1993, ŠTYS 1961). Here we adopt the subdivisions of SCHAEFER (1993) for this infraorder - viz. Aradoidea + Trichophora (Lygaeoidea, Pyrrhocoroidea, Pentatomoidea, and Coreoidea). Five families are nowadays recognized within the superfamily Coreoidea [Alydidae AMYOT \& SERVILLE, 1843 (broadheaded bugs); Coreidae LEACH, 1815 (leaf-footed bugs and squash bugs); Hyocephalidae BERgROTH, 1906 (no vernacular name); Rhopalidae AMYot \& SERVILLE, 1843 (scentless plant bugs); and Stenocephalidae DALLAS 1852 (spurge bugs)]. A monospecific Miocene family Trisegmentatidae ZHANG, SUN \& ZHANG, 1994 is also included in this superfamily but the assignment and placement of this fossil is quite dubious (ZHANG et al. 1994). Coreoidea as a whole is part of a close-knit group with the Lygaeoidea and Pyrrhocoroidea. HENRY (1997) presented a phylogeny of the Pentatomomorpha where Coreoidea were recovered as sister to Pyrrhocoroidea, and these together as the sister group of Lygaeoidea (+ Idiostoloidea sensu ŠTYS \& KERZHNER 1975). Based on a molecular phylogenetic analysis, LI et al. (2005) considered that relationships among members of Coreoidea, Lygaeoidea and Pyrrhocoroidea are not well established and that it is likely that these three superfamilies are polyphyletic, concluding that a revision and redefinition are needed for these lineages. XIE et al. (2005) also questioned the monophyly of these superfamilies. WeIRAUCH \& SCHUH (2011) indicated that 'Cladistic analyses for three of the superfamilies, the Aradoidea, Coreoidea, and Pyrrhocoroidea, are missing to date', reinforcing the opinion of LI et al. (2005). Nevertheless, TiAN et al. (2011) concluded after a molecular phylogenetic analysis that the superfamilies Pentatomoidea, Lygaeoidea, Coreoidea, and Pyrrhocoroidea are monophyletic.

Fossil representatives of Coreoidea are known since the Late Triassic and some Mesozoic genera have been described from rock impressions, generally on the basis of rather poorly preserved fossils not showing essential structures (pretarsal structures, trichobothria, etc.) for accurate attribution to the superfamily (see below and summary in YAO et al. 2004, 2006a).

Here we describe a new hemipteran fossil, Yuripopovina magnifica gen. n., sp. n., belonging to a new family within Coreoidea. The fossil is integrated to a cladistic analysis in order to explore its affinities within the superfamily. The fossil is preserved as an inclusion in Lower Cretaceous amber from Lebanon. To date 21 hemipterans have been studied from Lebanese amber (SCHLEe 1970, FenNAH 1987, AZAR et al. 1999, HeIE \& AZAR 2002, SzWedo 2007, Koteja \& AZAR 2008, Ouvrard et al. 2010, AZAR \& NeL 2010, WĘGIEREK \& GRIMALDI 2010, SZWEDO et al. 2011, DROHOJOWSKA \& SZWEDO 2011).

\section{Acknowledgements}

The authors are thankful to Prof. Ryszard Szadziewski and Dr Jacek Szwedo for their kind invitation to contribute to this special volume. This paper is a contribution to the 
project "Insects in the Lower Cretaceous Lebanese amber: taxonomy, palaeobiodiversity and evolution", under cooperative agreements between the Lebanese University (Beirut); MIZ (Museum and Institute of Zoology), Polish Academy of Sciences, Warsaw; University of Gdansk; and the Polish Academy of Sciences, Krakow project "Origin and evolution of biodiversity of Europe and the Middle East". This paper is a contribution to the team project "Biodiversity: Origin, Structure, Evolution and Geology" awarded to D.A. by the Lebanese University.

\section{MATERIAL AND METHODS}

The material described here was recovered from the locality Al-Rimthaniyyeh - Ain El Shqaq in the village of Bouarij, Caza Zahleh, Beqaa, central Lebanon. The amber piece containing the inclusion was cut, shaped and polished, before inclusion in a glass coffin with Canada balsam as medium. The specimen was examined with a Nikon SZ10 stereomicroscope, an Olympus SZX9 stereomicroscope, and a Leitz Laborlux-12 compound microscope, all equipped with a camera lucida for line drawings. Photographs were made with an Olympus digital camera.

Cladistic analysis was performed using PAUP 4.0 Beta 10 version (SWOFFORD 2001). In addition to our fossil, Yuripopovina magnifica, the characters and taxa used are those of HENRY (1997), which is the only available phylogenetic analysis of the Pentatomomorpha. All characters are unordered and equally weighted, in contrast to the analysis of HENRY (loc. cit.). The Aradidae are chosen as an outgroup as in HENRY (loc. cit.). A heuristic analysis for the entire matrix was performed, the results of which were confirmed by an exhaustive analysis of the Coreoidea + Pyrrhocoroidea (same topology for this clade).

\section{SYSTEMATIC PALAEONTOLOGY}

Order: Hemiptera LINNAEUS, 1758

Suborder Heteroptera LATREILLE, 1810

Infraorder: Pentatomomorpha Leston, PendergRAST \& SOUTHWOOD, 1954

Superfamily: Coreoidea REUTER, 1910

\section{Family Yuripopovinidae fam. $n$.}

\section{Type genus}

Yuripopovina gen. n.

Diagnosis

Coreoid with enlarged head; large spherical compound eyes slightly 'pedunculate'; 
ocelli present on elevate tubercle situated anteriorly to lower margin of compound eyes; antenna four-segmented; all segments cylindrical; thorax with wide pronotum with sinuous flank; collar well developed, circular, not depressed dorso-ventrally, callus well developed; metathoracic scent-gland auricles large and conspicuous; presence of a spur on metathoracic third axillary sclerite; tarsi trimerous, tibiae fusiform setose without modified setae; wings membranous and well developed, forewing corium hyaline with three longitudinal veins and two large cells, costal vein thickened apically, membrane with more than five anastomosing veins; abdomen with sternites 3, 4, and 5 fused; trichobothria in lateral position on sternites 5-8 and sublateral on sternites 3 and 4; ovipositor laciniate.

\section{Genus Yuripopovina gen. n.}

\section{Etymology}

The new genus-group name honours our friend, Prof. Yuri Alexandrovich Popov, world specialist on Hemiptera. The name is feminine.

\section{Type species}

Yuripopovina magnifica sp. n., here designated.

\section{Diagnosis}

Mandibular plates unarmed, not covering antennae; mesoscutum well developed, armed with rectangular globose tubercle distally; scutellum with strongly raised marginal carinae ending at apex in a laterally compressed lobe; forewing with veins of corium lacking rows of spines.

\section{Yuripopovina magnifica sp. $\mathrm{n}$.}

(Figs 1-21)

\section{Etymology}

The specific epithet refers to the magnificent state of preservation of the holotype.

\section{Material examined}

Holotype: TAR 173; female, Azar Coll., provisionally deposited in the Muséum National d'Histoire Naturelle, Paris.

\section{Type locality and horizon}

Early Cretaceous, Upper Barremian-Lower Aptian, in the village of Bouarij, Caza Zhahleh, Mouhafazit El-Beqaa (Beqaa district), Central Lebanon.

\section{Diagnosis}

Body length ca. $4.8 \mathrm{~mm}$; clypeus unarmed, without spines, apically globose, extending anteriorly beyond mandibular plates; bucculae not extending posteriorly beyond base of antennae; interocular distance less than width of anterior margin of scutellum; forewing reaching abdominal apex. 


\section{Description}

Body length $4.84 \mathrm{~mm}$, width $1.37 \mathrm{~mm}$ (Figs 1-3).

Head enlarged across compound eyes, $1.03 \mathrm{~mm}$ wide and $0.72 \mathrm{~mm}$ long, nearly triangular; compound eyes large, protuberant and spherical, $0.37 \mathrm{~mm}$ long and $0.28 \mathrm{~mm}$ wide (Figs 4-7); vertex broad, width $0.45 \mathrm{~mm}$; two ocelli well elevated on a tubercle and situated on a line where lower margin is distinctly anterior to lower margin of compound eyes (Figs 4, 6); frons prominent and setose; clypeus unarmed, setose but without spines, apically globose, extending anteriorly beyond mandibular plates; mandibular plates unarmed; head in front of compound eyes unarmed; bucculae not extending posteriorly beyond base of antennae (Fig. 8); mandibular plates not covering antennae; antenna foursegmented, all segments cylindrical, with apical end slightly broader than posterior; first antennal segment robust, thickest, $0.28 \mathrm{~mm}$ long and $0.1 \mathrm{~mm}$ wide; second segment longest, $1.15 \mathrm{~mm}$ long and $0.075 \mathrm{~mm}$ wide; third segment $1.075 \mathrm{~mm}$ long and $0.075 \mathrm{~mm}$ wide; rostrum four-segmented, length $2.34 \mathrm{~mm}$, extending posteriorly beyond insertion of mesocoxae; rostral segment I cylindrical, stout and reaching posterior gular region, 0.52 $\mathrm{mm}$ long, $0.07 \mathrm{~mm}$ wide; segment II cylindrical, $0.31 \mathrm{~mm}$ long, $0.04 \mathrm{~mm}$ wide; segments III cylindrical, slender and slightly curved, $0.94 \mathrm{~mm}$ long, $0.03 \mathrm{~mm}$ wide; segment IV length $0.52 \mathrm{~mm}$, width $0.05 \mathrm{~mm}$.

Thorax with pronotum wider than long, $1.38 \mathrm{~mm}$ wide, $1.13 \mathrm{~mm}$ long, nearly trapeziform with sinuous flanks; collar well developed, circular, not depressed dorsoventrally; callus well developed with two distinct transverse prominences; postero-lateral marginal lamella well developed, strong, angular, directed upward; posterior lobe of pronotum dorsally bulbous; posterior margin of pronotum convex laterally and concave medially, strengthened laterally with well-developed ridged border directed upward; mesoscutum well developed, armed with rectangular globose tubercle distally; scutellum with strongly raised marginal carinae ending at apex in a laterally compressed lobe (Figs 9, 11); presence of a spur on metathoracic third axillary sclerite (Fig. 18); metathoracic scentgland auricles large and conspicuous (Fig. 19); legs with tarsi trimerous (Figs 13-15); mesofemora with a series of long posterior setae; tibiae fusiform setose without modified setae; respective lengths and widths of pro-, meso- and metafemora $0.98 \mathrm{~mm}, 0.15 \mathrm{~mm}$; $1.06 \mathrm{~mm}, 0.16 \mathrm{~mm}$; and $1.59 \mathrm{~mm}, 0.28 \mathrm{~mm}$; tibiae with apical spines on internal surface, respective lengths and widths of pro-, meso- and metatibiae $1.03 \mathrm{~mm}, 0.11 \mathrm{~mm} ; 1 \mathrm{~mm}, 0.1$ $\mathrm{mm} ; 1.45 \mathrm{~mm}, 0.1 \mathrm{~mm}$; protarsi I-III respectively $0.27 \mathrm{~mm}, 0.1 \mathrm{~mm}$, and $0.15 \mathrm{~mm}$; mesotarsi I-III respectively $0.28 \mathrm{~mm}, 0.1 \mathrm{~mm}$, and $0.15 \mathrm{~mm}$; metatarsi I-III respectively $0.33 \mathrm{~mm}, 0.11 \mathrm{~mm}$, and $0.21 \mathrm{~mm}$; pretarsi with large pulvilli padlike arising from claws (Fig. 20), paraempodia paired, setiform, arising between claws; wings membranous and well developed, forewing reaching abdominal apex, length $2.79 \mathrm{~mm}$, width $1.05 \mathrm{~mm}$, with veins of corium lacking rows of spines, corium with three longitudinal veins, membrane with more than five anastomosing veins (Figs 10, 12). 

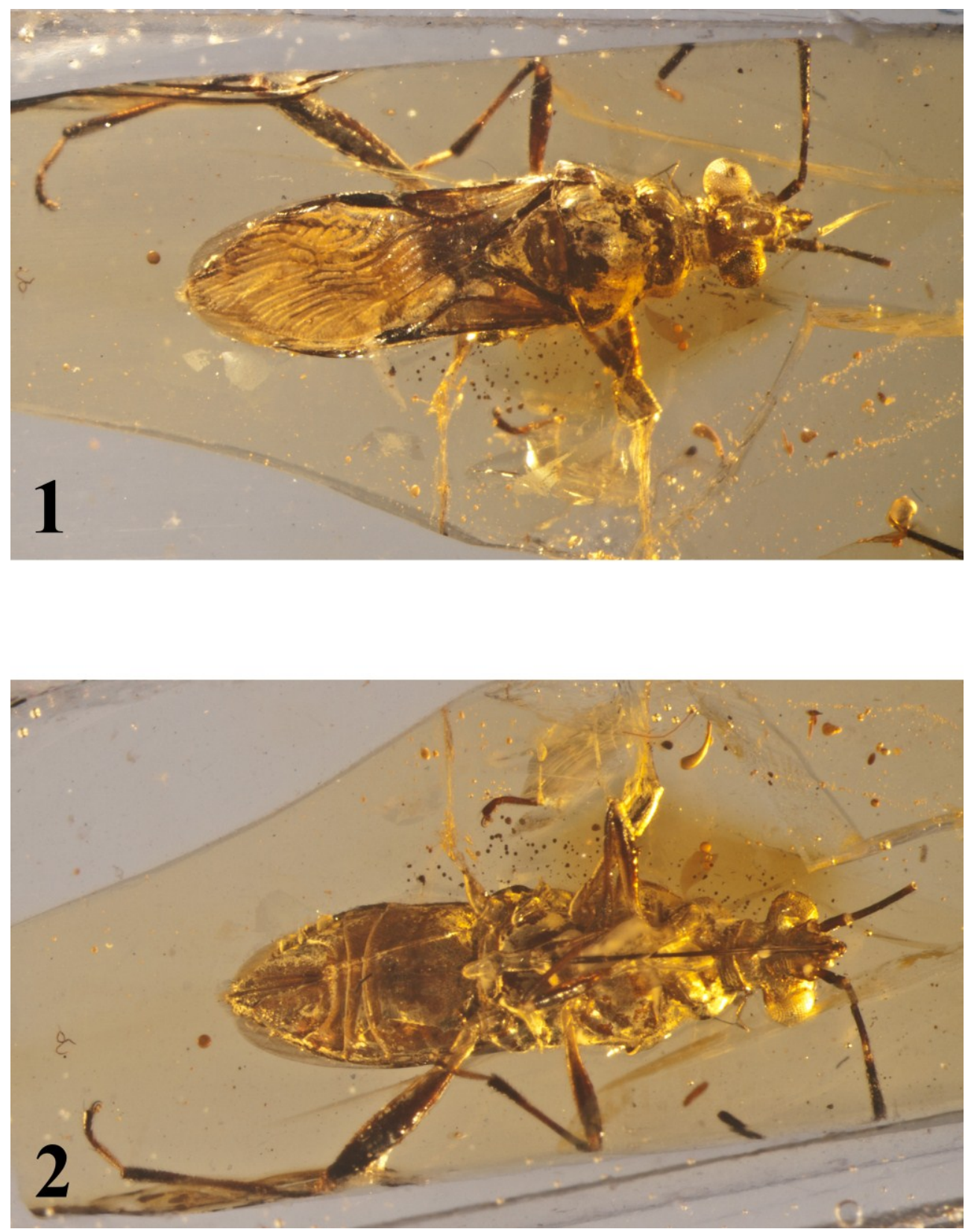

Figs 1-2. Yuripopovina magnifica gen. n., sp. n., holotype, TAR 173, female, habitus: 1 - dorsal view, 2 - ventral view. 


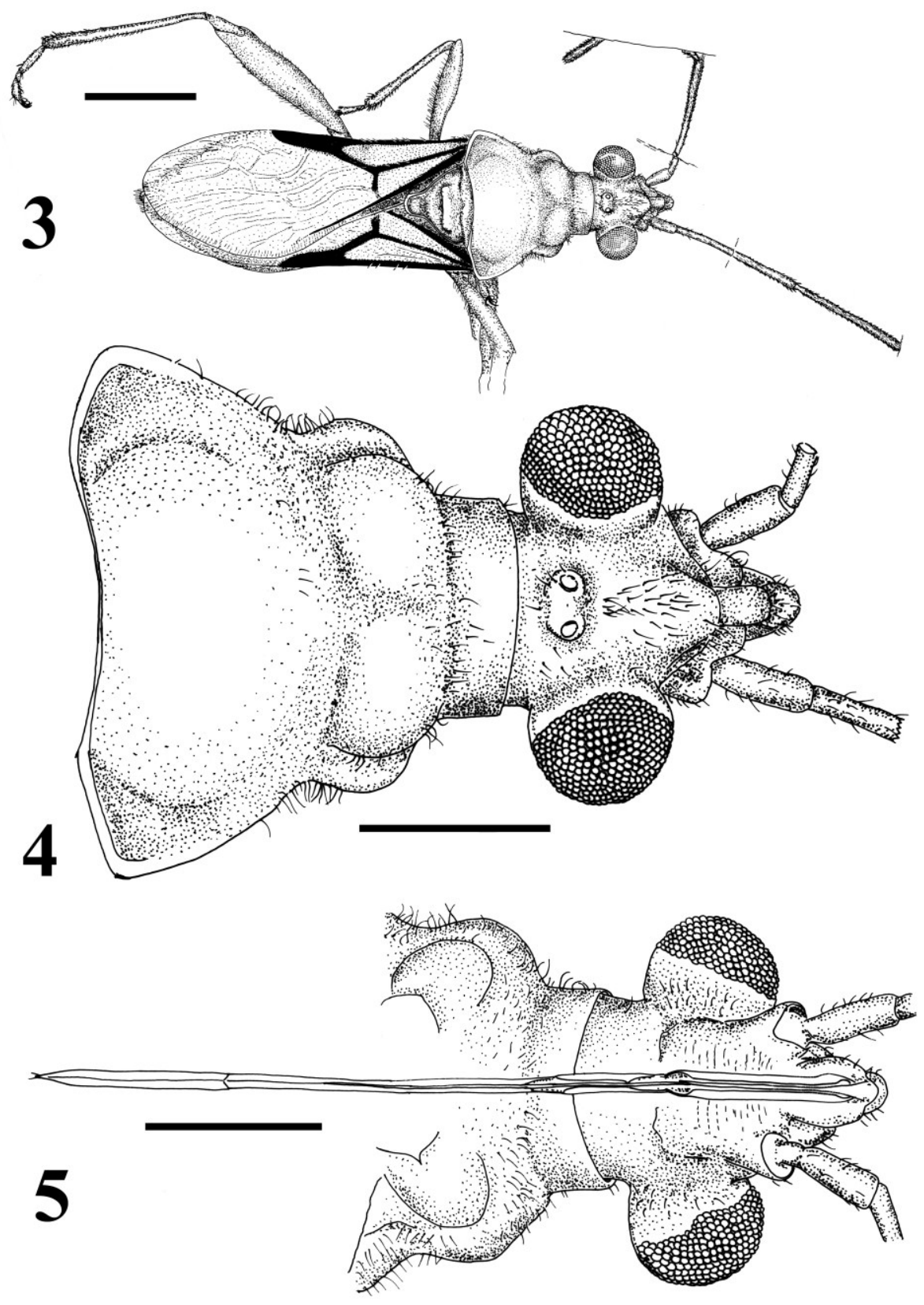

Figs 3-5. Yuripopovina magnifica gen. n., sp. n., holotype, TAR 173, female: 3 - habitus, dorsal view, scale bar $=1 \mathrm{~mm}, 4-$ head and pronotum, dorsal view, scale bar $=0.5 \mathrm{~mm}, 5-$ head, ventral view, scale bar $=0.5 \mathrm{~mm}$. 
Abdomen $1.83 \mathrm{~mm}$ long, $1.16 \mathrm{~mm}$ wide; sternites 3-5 fused but limits between sternites 3,4 , and 5 discernible by curved transverse depressions (Fig. 16); trichobothria pattern as in (Fig. 17), four on sternites 3 and 4, three on sternites 5, 6, 7, and 8; female genitalia as in (Fig. 21), ovipositor laciniate.
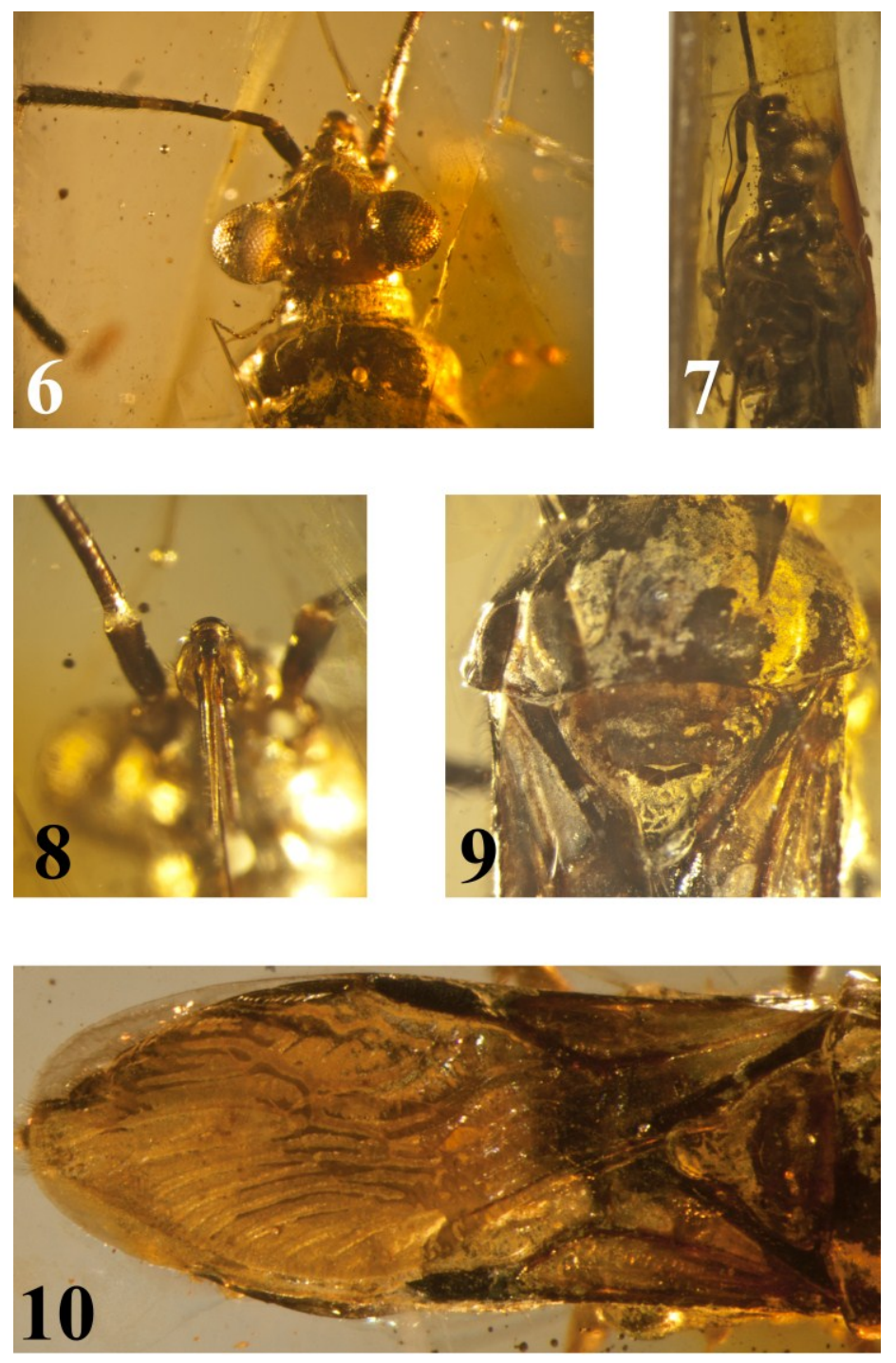

Figs 6-10. Yuripopovina magnifica gen. n., sp. n., holotype, TAR 173, female: 6 - head, dorsal view, 7 - head, lateral view, 8 - bucculae, 9 - scutellum, 10 - forewings. 

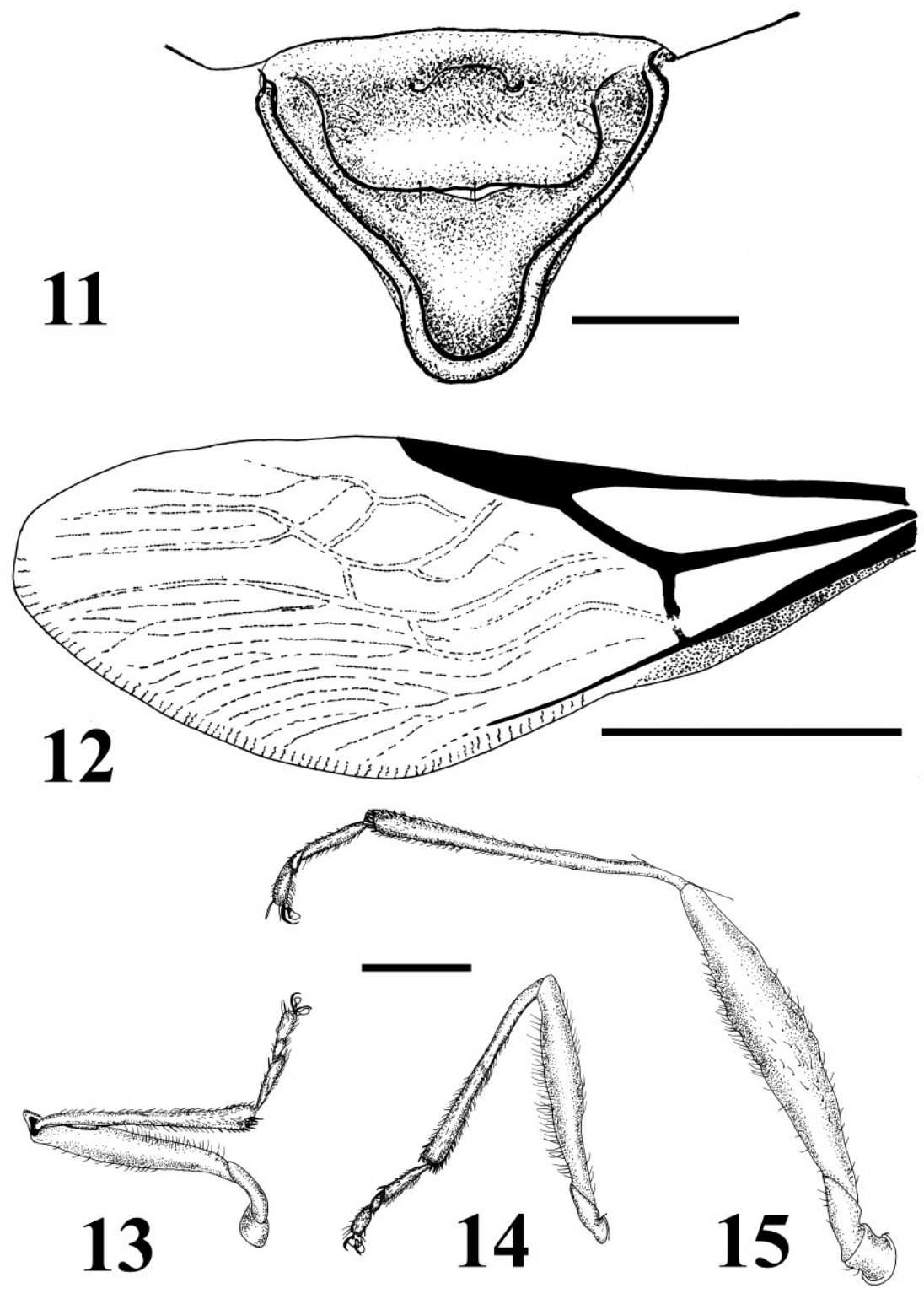

Figs 11-15. Yuripopovina magnifica gen. n., sp. n., holotype, TAR 173, female: 11 - scutellum, scale bar $=0.3 \mathrm{~mm}, 12-$ forewing, scale bar $=1 \mathrm{~mm}, 13-15-$ legs, scale bar $=0.5 \mathrm{~mm}$, foreleg (13), midleg (14), hindleg (15). 

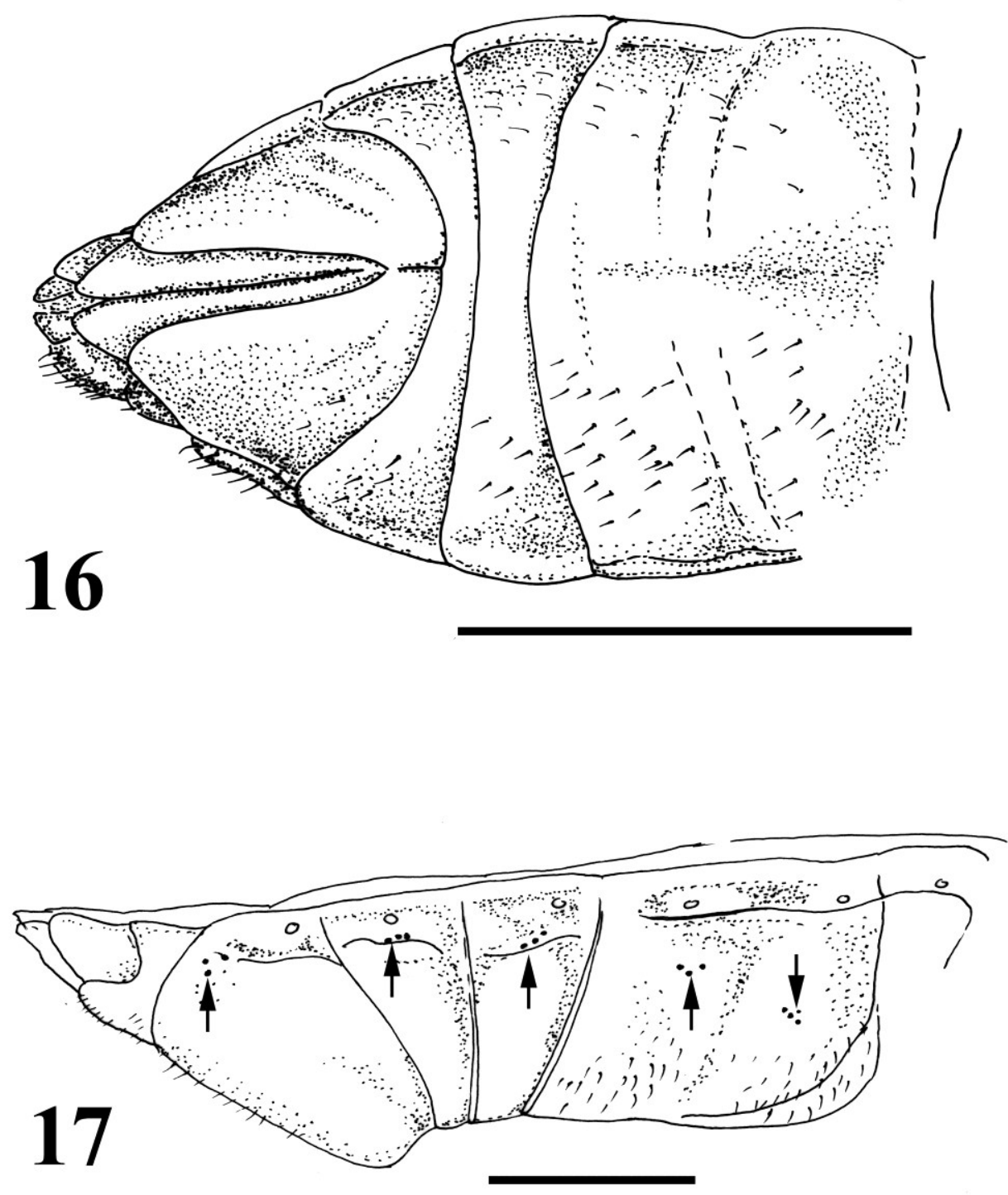

Figs 16-17. Yuripopovina magnifica gen. n., sp. n., holotype, TAR 173, female, abdomen: 16 ventral view, scale bar $=1 \mathrm{~mm}, 17$ - lateral view, arrows indicate trichobothria, scale bar $=0.5 \mathrm{~mm}$. 

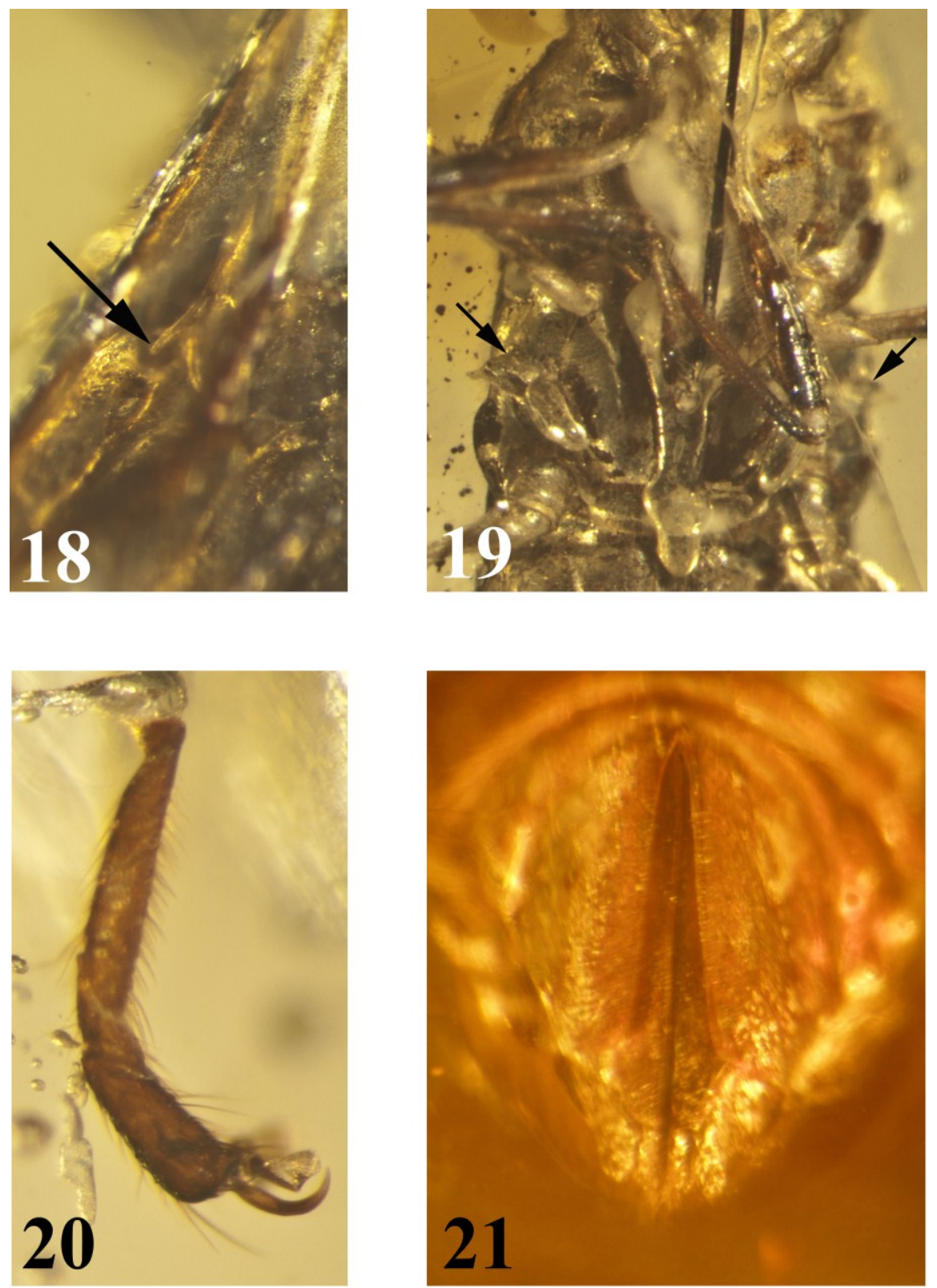

Figs 18-21. Yuripopovina magnifica gen. n., sp. n., holotype, TAR 173, female: 18 - spur on metathoracic third axillary sclerite (arrow), 19 - metathoracic scent glands (arrows), 20 - tarsus, 21 female genitalia. 


\section{DISCUSSION}

Following the keys of SCHUH \& SLATER (1995), Yuripopovina magnifica gen. et sp. n. would fall in the Pentatomomorpha owing to the following features: 1) compound eyes present; 2) head not constricted and divided into lobes; 3) head without trichobothria; 4) antennae longer than head; 5) abdominal sterna 3-7 with three trichobothria placed sublaterally. The structure of the tarsal pulvilli is also typical of the Pentatomomorpha (WHEELER et al. 1993).

Yuripopovina can be placed within Coreoidea owing to the combination of the following characters (after SCHAEFER 1965): ocelli present; antennae four-segmented, surpassing head; rostrum surpassing procoxae; first rostral segment distinct; scutellum never longer than one-half the length of the abdomen; scent gland apparatus and orifice usually well developed; clavus distinct; more than five membranal veins, these sometimes anastomosing; membranal veins originating from a vein parallel to apical border of corium; spur of metathoracic third axillary sclerite usually present; tarsi trimerous; pseudarolia present; abdomen with all spiracles ventral; trichobothria of fifth through seventh sternites all posterior to spiracle; female genitalia with gonocoxites VIII not fused to eighth paratergites.

In the analysis of HENRY (1997), the Coreoidea are not supported by any synapomorphy. Nevertheless, based on the phylogenetic analysis of HENRY (1997), Yuripopovina has one of the synapomorphies of the Coreoidea + Pyrrhocoidea, viz. the trichobothria of abdominal segment 4 medioventral. Accordingly, we included Yuripopovina in a phylogenetic analysis based on the matrix of HENRY (1997: 278). When the analysis was carried out without including Yuripopovina, we obtained 66 equally most parsimonious cladograms with length $=173$ steps, $\mathrm{CI}=0.41, \mathrm{RI}=0.67$, less resolved than the one obtained by HENRY (1997) after successive weighting of his characters. After integrating Yuripopovina, we obtained 66 most parsimonious cladograms of length $=177$ steps, $\mathrm{CI}=0.40$ and $\mathrm{RI}=0.65$. In the strict consensus cladogram Yuripopovina falls within the Coreoidea, but in a basal polytomy with Coreidae, Alydidae, Rhopalidae, and (Stenocephalidae + Hyocephalidae) (Fig. 22).

In our analysis the placement of Yuripopovina is supported by characters ' 6 state 0 ', ' 7 state 1', and ' 26 state 0 ', plus the more ambiguous characters ' 12 state 1 ' and ' 14 state 1 '.

Yuripopovina shares several characters with each of the different families of Coreoidea without however fitting in any of them. Overall Yuripopovina has a unique forewing venation, without equivalent among any Coreoidea, fossil or recent, with an apicallythickened, pterostigma-like costal vein and only two large cells separated by one longitudinal straight vein in a membraneous corium. A hyaline corium is also present in some extant Rhopalidae but without pterostigma-like structure and they generally have more cells in the corium than in Yuripopovina (HOEBEKE \& WHEELER 1982). 


\begin{tabular}{|c|c|}
\hline & $\begin{array}{c}\text { Character } \\
000000000111111111122222222223333333333444444444455555555 \\
123456789012345678901234567890123456789012345678901234567\end{array}$ \\
\hline Coreidae & 000110100000010000100000000100000230000001100022000201020 \\
\hline Alydidae & 000110100001010000100000000100000230000001100022000201020 \\
\hline Rhopalidae & 000100100001010000100000000100000230000001100022000201000 \\
\hline Stenocephalidae & $000110000001010000100000000101000130000001 ? 00022000201010$ \\
\hline Hyocephalidae & $000110000001010000100000000101000130000001 ? 00022000 ? 01010$ \\
\hline Larginae & 100101000000010000100000011201000130000001100022000200000 \\
\hline Physopeltinae & 100101000000100000100001011201000130000001100022000200000 \\
\hline Pyrrhocoridae & 100101000001100000100000010200000230000001100022000200000 \\
\hline Yuripopovina ${ }^{\dagger}$ & $100110100001 ? 1100110000100010000013 ? ? ? ? ? ? ? 00022000 ? ? ? ? ? ?$ \\
\hline Aradidae & 000001010101000000000000000000001230000000000000110000000 \\
\hline Pentatomoidea & 000000000001100000100000000300000230000000000011000000010 \\
\hline Idiostolidae & $000110000000000000110000000210000101100001 ? 10021001101000$ \\
\hline Henicocorinae & $000110000000000000 ? ? 0000000110000101100 ? 01000021001101000$ \\
\hline Berytidae & 002110121101011001021030010100100130000000010021000100100 \\
\hline Colobathristidae & $102110120000001001021020001100100 ? 30000011000021000100000$ \\
\hline Artheneinae & 000110000001010000120010010100010100001001000121000100001 \\
\hline Bledionotinae & 010110000000000000020020010100010100000001000121000111000 \\
\hline Blissinae & 000110000100010000020030001100010110000001000121000101000 \\
\hline Cryptorhamphinae & 001100011101011000121030010100000100000001000121000101000 \\
\hline Cymini & 001110011101011000021030010100000100000001000121000100100 \\
\hline Ninini & 101110111101011010021030010100000100001001000121000100000 \\
\hline Geocorinae & 010110000001000000020030000100010100001101000121000111000 \\
\hline Henestarinae & 010000000000010100120020000100010100000101010121000111000 \\
\hline Heterogastrinae & 100110000001010000120000001100010120010011000121000100000 \\
\hline Ischnorhychinae & 000000000010000100120040000100000120000101010121000100000 \\
\hline Lygaeinae & 000000000010000100120040000100000100001000000021000000000 \\
\hline Orsillinae & 000000000110010100120040001100000120000001010121000101000 \\
\hline Oxycareninae & 000000000100010000020010010100010121001001010021000101001 \\
\hline Pachygronthinae & 000110021001000000120000001100010120010001000121000101000 \\
\hline Psamminae & $000001010100010000 ? ? 113001010000110000000100000111010100 ?$ \\
\hline Plinthisini & 000110000001000000120000001100010100000101001121000100000 \\
\hline Rhyparochromini & 000110000001000000120001001100010100000101001121000100000 \\
\hline Malcinae & 102110111101011010021030110100000130000101010121000100000 \\
\hline Chauliopinae & 102110111101011010121030110100000130000101010121000101000 \\
\hline Piesmatidae & 000001010101010000021130010100001130000001000001110100101 \\
\hline
\end{tabular}

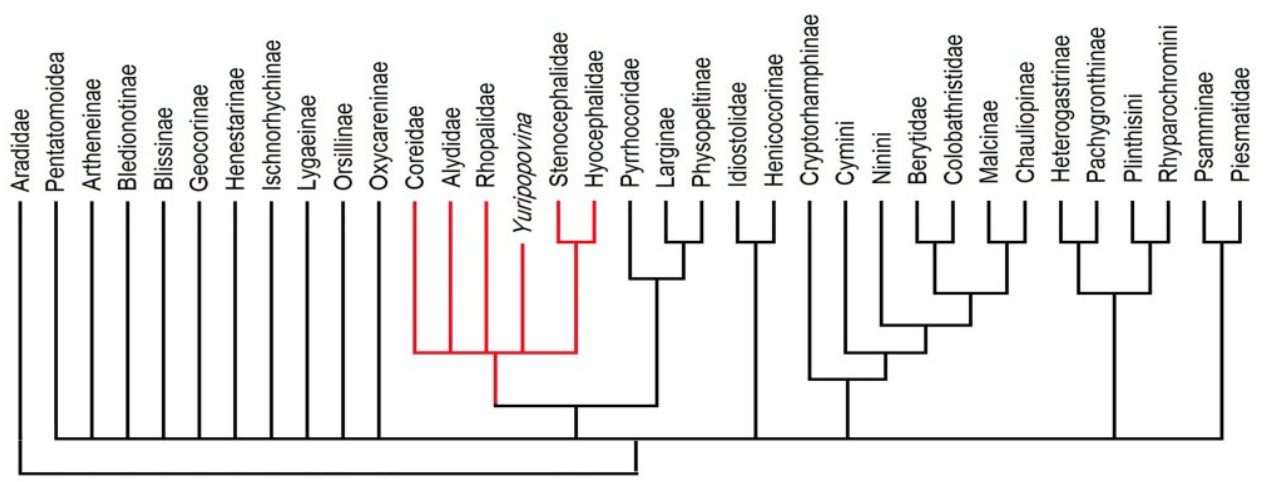

Fig. 22. Matrix with taxa used in the phylogenetic analysis, and strict consensus cladogram of Pentatomomorphan bugs including Yuripopovina. 
In some Hyocephalidae, the corium has two-three large cells but of different shape and they have no pterostigmal structure, ŠTYS 1964). This unique venational arrangement represents an autapomorphy supporting the new family.

Among Mesozoic Coreoidea, the Jurassic genus Monstrocoreus Popov, 1968, currently considered as an alydid (YAO et al. 2008), also has a two-celled but not membraneous corium (POPOV 1968). The coreoids Miracorizus and Longiclavula YAO et al., 2006 also have a non-membraneous corium (YAO et al. 2006a). The three other Chinese Mesozoic genera Originicorizus, Quatlocellus, and Grandicaputus have a corium with more than two cells (YAO et al. 2006b). The putative Triassic coreoid Kerjiecoris LIN, 1992 is a very poorly preserved, incomplete fossil, and it is impossible to compare it with Yuripopovina or even other coreoids (LIN 1992). The Jurassic coreoid Karatavocoris BECKER-MIGDISOVA, 1962 is also a poorly preserved fossil with unclear affinities (BECKER-MIGDISOVA \& POPOV 1962). Sinocoris Hong, 1983, Hebeicoris HoNG, 1983, and Coroides HoNG, 1987 are similarly based on exceptionally poor fossils, but all with a habitus significantly different from that of Yuripopovina (HoNG 1983, 1987). The Mesozoic genus Neocorum LIN, 1977 is based on an isolated forewing, rather poorly preserved but exhibiting an apicallythickened costal vein, similar to that of Yuripopovina (LIN 1977). Weichangicoris HONG, 1984 has the head and pronotum subequal in length, quite unlike that of Yuripopovina.

\section{CONCLUSION}

Yuripopovina is the first record of Coreoidea in Mesozoic amber. Owing to the exceptional preservation of the fossil it was possible to observe structures crucial for a relatively accurate attribution to this superfamily. This has certainly not been the case for most of those Mesozoic taxa currently attributed to Coreoidea and found as compressions in lacustrine deposits. For example, one of the best preserved fossils, Miracorizus punctatus YAO et al., 2006, was placed in the Coreoidea based solely on 'numerous longitudinal veins in its membrane', a feature which is not an apomorphy of this superfamily. Consequently, Yuripopovina can be considered as the first truly accurate record of Mesozoic Coreoidea. The correct identification and affinities of compression fossil Pentatomomorpha remains a significant challenge toward understanding the evolutionary history of this major hemipteran radiation.

\section{REFERENCES}

Azar D., Fleck G., Nel A., Solignac M. 1999. A new enicocephalid bug, Enicocephalinus acragrimaldii, gen. n., sp. n., from the lower Cretaceous amber of Lebanon (Insecta, Heteroptera, Enicocephalidae). Estudios del Museo de Ciencias Naturales de Alava 14 (Número especial 2): 217-230. 
AzAR D., Nel A. 2010. The earliest fossil schizopterid bug (Insecta: Heteroptera) in the Lower Cretaceous amber of Lebanon. Annales de la Société Entomologique de France (N.S.) 46(1-2): 193-197.

Becker-Migdisova E.E., Popov Yu.A. 1962. Some new Heteroptera from the Jurassic of Karatau. Paleontologicheskij Zhurnal 1962(2): 74-82.

DrohojowsKa J., Szwedo J. 2011. A new whitefly from Lower Cretaceous Lebanese amber (Hemiptera: Sternorrhyncha: Aleyrodidae). Insect Systematics \& Evolution 42: 179-196.

FENNAH R.G. 1987. A new genus and species of Cixiidae (Homoptera, Fulgoroidea) from Lower Cretaceous amber. Journal of Natural History 21(5): 1237-1240.

HeIE O., AZAR D. 2000. Two new species of aphids found in Lebanese amber and a revision of the family Tajmyraphididae Kononova, 1975 (Hemiptera, Sternorrhyncha). Annals of the Entomological Society of America 93(6): 1222-1225.

HENRY T.J. 1997. Phylogenetic analysis of family groups within the infraorder Pentatomomorpha (Hemiptera: Heteroptera), with emphasis on the Lygaeoidea. Annals of the Entomological Society of America 90(3): 275-301.

HoEBeKe E.R., WheELER A.G. Jr. 1982. Rhopalus (Brachycarenus) tigrinus, recently established in North America, with a key to the genera and species of Rhopalidae in eastern North America (Hemiptera: Heteroptera). Proceedings of the Entomological Society of Washington 84(2): 213224.

Hong Y.-C. 1983. Middle Jurassic fossil insects in North China. Geological Publishing House, Beijing, $223 \mathrm{pp}$.

HoNG Y.-C. 1987. The study of Early Cretaceous insects of Kezuo, West Liaoning. Professional Papers of Stratigraphy and Paleontology 18: 76-91.

Koteja J., AZAR D. 2008. Scale insects from Lower Cretaceous amber of Lebanon. Alavesia 2: 133167.

Li H.-M., Deng R.-Q., WANG J.-W., Chen Z.-Y., JiA F.-L., WANG X.-Z. 2005. A preliminary phylogeny of the Pentatomomorpha (Hemiptera: Heteroptera) based on nuclear 18S rDNA and mitochondrial DNA sequences. Molecular Phylogenetics and Evolution 37(2): 313-326.

LIN Q.-B. 1977. Insect fossils from Yunnan province, China. [In:] Mesozoic fossils from Yunnan province, China, 2, Nanjing Institute of Geology and Paleontology, Academia Sinica (publ.), Beijing, Science Press, pp.: 373-382.

LIN Q.-B. 1992. Late Triassic insect fauna from Toksun, Xianjiang. Acta Palaeontologica Sinica 31(3): 313-335.

Ouvrard D., Burckhardt D., AZAR D., Grimaldi, D. 2010. Non-jumping plant lice in Cretaceous amber (Hemiptera: Sternorrhyncha: Psylloidea). Systematic Entomology 35: 172-180.

Popov YU.A. 1968. True Heteroptera of the Jurassic fauna. [In:] RoHDENDORF B.B. (ed.). Yurskie nasekomye Karatau. [Jurassic insects of Karatau.] Akademiya nauk SSSR Otdelenie Obshchej Biologii, Moscow, pp.: 99-113.

SCHAEFER C.W. 1965. The morphology and higher classification of the Coreoidea (Hemiptera Heteroptera). Part 3. The families Rhopalidae, Alydidae, and Coreidae. Miscellaneous Publications of the Entomological Society of America 5(1): 1-76.

SCHAEFER C.W. 1993. The Pentatomomorpha: an annotated outline of its systematic history. European Journal of Entomology 90: 105-122.

SCHLEE D. 1970. Insekten fossilien aus der unteren Kreide. 1: Verwandtschaftsforschung an fossilen und rezenten Aleyrodina (Insecta, Hemiptera). Stuttgarter Beiträge zur Naturkunde, (A) 213: 1-72.

SChUH R.T., Slater J.A. 1995. True bugs of the World (Hemiptera: Heteroptera). Classification and natural history. Comstock Publishing Associates, Cornell University Press, Ithaca and London, i$\mathrm{xii}+1-336$.

SwOFFord D.L. 2001. PAUP*: Phylogenetic Analysis Using Parsimony (*and other Methods) 
Version 4. Sunderland, Sinauer Associates.

ŠTYS P.1961. Morphology of the abdomen and female ectodermal genitalia of the trichophorous Heteroptera and bearing on their classification. 11th International Congress of Entomology, Wien (1960) 1: 37-43.

ŠTYS P. 1964. The morphology and relationship of the family Hyocephalidae (Heteroptera). Acta Zoologicae Academiae Scientiae Hungaricae 10(1-2): 229-262.

ŠTYS P., KeRZHNER I.M. 1975. The rank and nomenclature of higher taxa in the Heteroptera. Acta Entomologica Bohemoslovaca 72: 65-79.

SzwEDO J. 2007. Nymphs of a new family Neazoniidae fam. n. (Hemiptera: Fulgoromorpha: Fulgoroidea) from the Lower Cretaceous Lebanese amber. African Invertebrates 48: 127-143.

Szwedo J., AZAR D., ZiADÉ K. 2011. The first Progonocimicidae (Insecta: Hemiptera: Coleorrhyncha) from Lower Cretaceous Lebanese amber. Insect Systematics \& Evolution 42(2): 161-177.

Tian X.-X., XiE Q., Li M., GaO C.-Q., Cui Y., BU W.-J. 2011. Phylogeny of pentatomomorphan bugs (Hemiptera-Heteroptera: Pentatomomorpha) based on six Hox gene fragments. Zootaxa 2888: 5768.

WĘGIEREK P., GRIMALDi D.A. 2010. A new subfamily of aphids (Hemiptera, Aphidomorpha) from the Early Cretaceous Lebanese amber with a description of the oldest apterous morphs. Acta Geologica Sinica (English Edition) 84(4): 665-672.

Weirauch C., Schuh R.T. 2011. Systematics and evolution of Heteroptera: 25 years of progress. Annual Review of Entomology 56: 487-510.

WheEler W., SchuH R.T., BANG R. 1993. Cladistic relationships among higher groups of Heteroptera: congruence between morphological and molecular data sets. Entomologica Scandinavica 24(3): 121-137.

XIE Q., BU W.-J., Zheng L. 2005. The bayesian phylogenetic analysis of the 18S rRNA sequences from the main lineages of Trichophora (Insecta: Heteroptera: Pentatomomorpha). Molecular Phylogenetics and Evolution 34(2): 448-451.

YAO Y.-Z., CAI W.-Z., REN D. 2004. The fossil Heteroptera of China: a review of present knowledge. Acta Zootaxonomica Sinica 29(1): 33-37.

YAO Y.-Z., CAI W.-Z., REN D. 2006a. The first discovery of fossil rhopalids (Heteroptera: Coreoidea) from Middle Jurassic of Inner Mongolia, China. Zootaxa 1269: 57-68.

Yao Y.-Z., CAi W.-Z., Ren D., Shin C.-K. 2006b. New fossil rhopalids (Heteroptera: Coreoidea) from the Middle Jurassic of Inner Mongolia, China. Zootaxa 1384: 41-58.

Yao Y.-Z., CAI W.-Z., Ren D. 2008. New Jurassic fossil true bugs of Pachymeridiidae (Hemiptera: Pentatomomorpha) from Northeast China. Acta Geologica Sinica (English Edition) 82(1): 35-47.

Zhang J.-F., Sun B., Zhang X. 1994. Miocene insects and spiders from Shanwang, Shandong. Science Press, Beijing, China, i-v + 1-298.

\section{APPENDIX}

List of characters used in cladistic analysis (adapted from HENRY 1997):

1- Shape of head and compound eye: (0) head not broad, compound eyes simple not stylate; (1) head broad, compound eyes stylate;

2- Shape of compound eyes: (0) round or oval; (1) reniform or kidney-shaped;

3- Suture between ocelli and compound eyes: (0) absent; (1) present;

4- Gular groove: (0) absent; (1) present; 
5- Buccula: (0) long, narrow, extending one-half length of head or more; (1) very short or reduced;

6- Ocelli: (0) present; (1) absent;

7- Antennal bases: (0) base arising below level of compound eye (infericorn); (1) base arising above level of compound eye (supericorn);

8- Antennal segment I: (0) short, slender; (1) short, stout, barrel shaped; (2) very long, longest of four segments;

9- Antennal segment II: (0) uniformly slender or gradually widened over entire length; (1) clavate apically;

10- Antennal segment IV: (0) slender, not modified or clubbed, similar to segment II and III; (1) clubbed, thickened and fusiform, or globose;

11- Pronotal calli: (0) smooth or punctuate, but without transverse impressed line; (1) narrow impressed line or transverse groove present across each callus;

12- Lateral margin of pronotum: (0) smoothly rounded; (1) bluntly to sharply carinate;

13- Mesosternum: (0) smooth; (1) possessing a distinct keel;

14- Mesosternum: (0) not grooved; (1) distinctly grooved to receive rostrum;

15- Posterior lobuli on pronotum: (0) absent; (1) present;

16- Scutellum with cross-shape pattern on dorsal surface: (0) absent; (1) present;

17- Scutellum apical shape: (0) simple, unmodified; (1) bifid;

18- Scutellum armature: (0) absent; (1) armed with medium carinae, conical or globose tubercle, or slender spine;

19- Hamus on hindwing: (0) absent; (1) present;

20- Veins on hemelytral membrane: (0) numerous anastomosing veins and closed cell; (1) 6-8 or more simple veins, with a basal cell; (2) only 3-4 simple veins, basal cell almost always absent;

21- Clavus: (0) impunctate; (1) distinctly punctuate;

22- Areolate hemelytra: (0) no; (1) yes;

23- Position of spiracles on abdomen: (0) all ventral; (1) only II dorsal, remainder ventral; (2) II, III, and IV dorsal, VI andVII ventral; (3) II, III, IV, V and sometimes VI dorsal, VII dorsal or on ventral edge; (4) all dorsal;

24- Segmental suture of abdomen: (0) all complete; (1) suture 4 and 5 incomplete;

25- Connexival 'horn' or processes: (0) absent; (1) present;

26- Inner laterotergite of abdomen: (0) present; (1) absent;

27- Ventral laterotergite of abdomen: (0) absent; (1) present;

28- Fusion of abdominal sterna: (0) all segments separate; (1) sterna 2-4 fused; (2) sterna 2-6 fused; (3) sterna 2-7 fused;

29- Connexivum on segment VII: (0) present; (1) absent;

30- Articulation of paratergite VIII: (0) does not articulate with gonocoxites VIII; (1) articulates with gonocoxites VIII;

31- Articulation of metacoxae: (0) directly laterally; (1) directed posterolaterally; 
32- Profemora: (0) slender or evenly thickened; (1) enlarged;

33- Number of tarsal segments: (0) 3; (1) 2;

34- Type of ovipositor: (0) lanceolate with gonoplacs; (1) lanceolate without gonoplacs; (2) platelike;

35- Sternite VII of female: (0) sternite VII split by ovipositor; (1) sternites VI and VII split by ovipositor; (2) sternites V VI and VII split by ovipositor; (3) sternite VII not split by ovipositor;

36- Spermatheca : (0) present; (1) absent or vestigial;

37- Membranous sac replacing spermatheca: (0) absent; (1) present;

38- In male, conjunctival inflatability: (0) inflatable; '1) not inflatable;

39- Phallothecal process: (0) absent; (1) present;

40- Vestigial helicoid process: (0) absent; (1) present;

41- Phallosome shape: (0) phallosome not elliptical and without tubular vesicae; (1) phallosome elliptical with an elongate desclerotized tubular vesicae;

42- Microsome: (0) absent; (1) present;

43- Sex chromosomes: (0) XY; (1) X0;

44- Pubescence: (0) simple; (1) silky or woolly;

45- Head trichobothria: (0) absent; (1) present;

46- Trichobothrial pads: (0) absent; (1) present;

47- Trichobothrial ground-plan numbers per segment: (0) absent; (1) 2; (2) 3;

48- Position of trichobothria on abdominal segment IV: (0) absent; (1) lateral; (2) medioventral;

49- Number of trichobothria on abdominal segment IV: (0) 1-3; (1) absent;

50- Number of trichobothria on abdominal segment V: (0) 1-3; (1) absent;

51- Length of trichobothria: (0) long, easily distinguished from simple setae; (1) short, difficult to distinguish from similarly short simple setae;

52- Number of salivary gland lobes: (0) 1-2; (1) 3; (2) 4;

53- Shape of dorsal abdominal scent gland suture in nymphs: (0) all sutures straight or transverse; (1) sutures between segment 4 and 5 , and 5 and 6 projected posteriorly;

54- Dorsal abdominal scent gland between segments 3 and 4 in nymphs: (0) present; (1) absent;

55- Dorsal abdominal scent gland between segments 5 and 6 in nymphs: (0) present; (1) absent;

56- Dorsal abdominal scent gland opening in nymphs: (0) single; (1) double separate; (2) double, separated on raised bumps;

57- Eclosion fractures on eggs: (0) simple slit; (1) hexagonal.

Received: September 14, 2011

Accepted: October 10, 2011 